\title{
SPECIES DIVERSITY OF BRYOPHYTES AND FERNS OF LAMPENFLORA IN GROTTA GIGANTE (NE ITALY)
}

\author{
VRSTNA RAZNOLIKOST MAHOV IN PRAPROTI LAMPENFLORE \\ V VELIKI JAMI V BRIŠČIKIH (SV ITALIJA)
}

\author{
Miris CASTELLO ${ }^{1}$
}

\begin{abstract}
UDC 582.3:551.442(450.361)

Miris Castello: Species diversity of Bryophytes and ferns of lampenflora in Grotta Gigante (NE Italy)

Lampenflora consists of phototrophic organisms which grow near artificial light. In caves with artificial lighting, a vegetation of aerophytic cyanobacteria and algae, bryophytes and ferns can be found around lamps; these communities represent an alteration of the underground environment and may cause damages both to speleothems and cave fauna. The development of lampenflora is a typical problem for show cave management. A floristic research of bryophytes and ferns (land plants) of lampenflora was carried out in 2012 in Grotta Gigante, a very well-known show cave of the Trieste Karst (NE Italy), in order to compile a species inventory. 26 sites near artificial lights of different kinds were sampled in the dark zone of the show cave. 16 moss species and 2 ferns were found; no liverworts were observed. The most common species are the mosses Eucladium verticillatum, Fissidens bryoides, Oxyrrhynchium schleicheri, Rhynchostegiella tenella and the fern Asplenium trichomanes; 7 moss species were found only in one to two sites. Some moss species belong to the flora of natural cave entrances of the Italian Karst, while other are typical of disturbed, open habitats. Various moss species and $A$. trichomanes are colonizing areas around LEDs and fluorescent lamps installed in 2009 along the cave's pathways for safety lighting. Species richness of bryophytes and ferns of lampenflora in Grotta Gigante is the highest compared to other recently investigated show caves in the neighbouring Slovenia. Lampenflora of Grotta Gigante conforms to that found in other Slovenian show caves studied starting from the ' 40 . The main ecological factors affecting lampenflora identified in this work are: light intensity, water availability, type of substrate, morphological features of surfaces, presence of clay. Aspects of species ecology and distribution in the cave are discussed.
\end{abstract}

Keywords: bryophytes, ferns, lampenflora, show caves, Grotta Gigante, Italy.

\section{Izvleček \\ UDK 582.3:551.442(450.361) \\ Miris Castello: Vrstna raznolikost mahov in praproti lampen- flore $v$ Veliki jami $v$ Briščikih (SV Italija)}

Lampenfloro sestavljajo fototrofni organizmi, ki rastejo v bližini umetne svetlobe. V jamah $\mathrm{z}$ umetno razsvetljavo lahko okoli luči najdemo različno vegetacijo, od aerotrofnih cianobakterij in alg do mahov in praproti. Te skupnosti predstavljajo spremembo podzemnega okolja in lahko povzročijo poškodbe kapnikov in jamske favne. Razvoj lampenflore je tipičen problem pri upravljanju jam. Leta 2012 so bile izvedene floristične raziskave mahov in praproti (kopenske rastline) v Veliki jami v Briščikih, znani turistični jami Tržaškega Krasa v SV Italiji, da bi ugotovili vrstno raznolikost lampenflore. $V$ temnem delu turistične jame je bilo vzorčevanih 26 lokacij v bližini različnih vrst umetnih luči. Najdenih je bilo 16 vrst mahu in dve vrsti praproti, medtem ko ni bilo opaženih nobenih jetrenjakov. Najbolj pogosti so mahovi Eucladium verticillatum, Fissidens bryoides, Oxyrrhynchium schleicheri, Rhynchostegiella tenella in praprot Asplenium trichomanes. Sedem vrst mahov je bilo najdenih le na dveh lokacijah. Nekatere vrste mahov pripadajo rastlinstvo naravnih jamskih vhodov na Italijanskem Krasu, medtem ko so druge značilne za površinske habitate. Različne vrste mahov in A. trichomanes naseljujejo območja okrog LED in fluorescentnih svetilk, v letu 2009 nameščenih ob jamskih poteh za varnostno razsvetljavo. Biodiverziteta mahov in praproti lampenflore $\mathrm{v}$ Veliki jami v Briščikih je najvišja v primerjavi $\mathrm{z}$ lampenfloro $\mathrm{v}$ drugih nedavno raziskanih turističnih jamamah v sosednji Sloveniji. Lampenflora iz Veliki jami v Briščikih ustreza tisti, najdeni v drugih slovenskih turističnih jamah, katerih proučevanja segajo v 40. Leta prejšnjega stoletja. Glavni ekološki dejavniki, ki vplivajo na lampenflora, opredeljenih v tem delu so: jakost svetlobe, razpoložljivost vode, vrsta podlage, morfološke značilnosti površin, prisotnost gline. Delo obravnava tudi različne vidike ekologije vrst in distribucijo $\mathrm{v}$ jami.

Ključne besede: mahovi, praproti, lampenflora, turistične jame, Veliki jami v Briščikih, Italija.

\footnotetext{
${ }^{1}$ Department of Life Sciences, University of Trieste, via Giorgieri 10, I-34127 Trieste, Italy, e-mail: castello@units.it, Received/Prejeto: 15.02.2013
} 


\section{INTRODUCTION}

The presence of phototrophic organisms in caves depends on the availability of light, essential for the photosynthetic process. In wild caves, aerophytic algae and land plants are naturally limited to the entrance parts, where there is at least some sunlight, while they can't grow in the dark, inner parts. In natural caves opened to the public and in artificial caves, the electrical lighting enables phototrophic organisms to grow in the underground: lit areas around lamps are colonized by cyanobacteria and algae, bryophytes, ferns, and exceptionally shoots of seed plants. They constitute what is called "lampenflora" (Dobàt 1963, 1998; Mulec 2012) or lamp flora, which includes all phototrophic organisms growing near artificial light sources in areas where they do not naturally occur because of the absence of sunlight.

These communities represent an alteration of the delicate cave environment and may cause damages both to speleothems and cave fauna.

Organisms of lampenflora influence lithogenic and litholitic processes. Biodeterioration of stony substrata caused by lampenflora is related to different, complex mechanisms involving the whole community of lit areas, both autotrophs and heterotrophs such as bacteria and fungi. Main mechanisms of biodeterioration of cave surfaces are: biofilm formation, colour changes and development of coloured patches, release of weak organic acids which in time can corrode limestone and formations, absorption of some chemicals from the substrate, protoncation exchange, carbon dioxide and oxygen fluxes due to photosynthesis, respiration or fermentation, $\mathrm{pH}$ changes (acid or alkaline reactions), the possible formation of an amorphous mix of dead organisms and calcium carbonate which may alter substrate surfaces (e.g. Warscheid \& Braams 2000; Mulec 2012).

Natural cave ecosystems are characterized by low levels of nutrients (Simon et al. 2007). The growth of primary producers provides an unnatural input of biomass, which is a source of nutrients available for both true cave-dwellers and occasional dwellers. Lampenflora may represent a threat to obligated cave-dwellers (troglobites), facilitating the proliferation of external opportunistic species which may compete with them and drive them to extinction (Mulec \& Kosi 2009; Mulec 2012).

Different mechanical, physical and chemical methods to control lampenflora growth have been proposed; discussions and reviews can be found in Johnson (1980), Olson (2006), Mulec and Kosi (2009) and Mulec (2011, 2012).

A key aspect to limit lampenflora growth is represented by lighting design. Main guidelines for show cave management to control lampenflora by adequate lighting are available in the literature (Olson 2006; Mulec \& Kosi
2009; Cigna 2012; Mulec 2012). According to them, great attention should be paid to type and power of lights and positioning of lamps, which should be installed at appropriate selected sites, at a distance from cave surfaces. Lighting time should be minimized, by switching lights on only when visitors are nearby. Lamp emission spectra should be poor in the wavelengths that are most effective for photosynthesis: in various caves, yellow-light or greenlight were shown to prevent or limit lampenflora growth, although they may have an unaestethic effect in cave lighting. LEDs seem to represent an effective solution for cave lighting as they feature low power consumption, long life and selected narrow emission spectra.

Show caves are provided with artificial lighting systems to attract visitors and to ensure public access and safety, of both the visitors and the staff. The control of lampenflora is a typical problem for show cave management: besides the alteration of the underground environment, the unwanted growth of lampenflora causes the development of more or less wide unaesthetic coloured patches on speleothems, walls and other parts of the cave illuminated by sufficient light.

A well-known show cave of Italy is Grotta Gigante, a very large cave which opens in the Trieste Karst. Grotta Gigante has a long tradition as a tourist cave, being opened to the public in 1908, when carbide lamps and candles were used for illumination. The first electrical lighting system was installed in 1957 and completely replaced in 2009 by a new one in accordance with laws, safety and environmental protection measures. The new lighting system consists of floodlights of different power and colour temperature to light the cave, speleothems and other objects; an emergency and safety lighting system consisting of LED lights and fluorescent lamps was installed along cave's pathways. A set of UVC germicidal lamps, provided with the 2008 Green certificate, was installed in different parts of the cave to inhibit the development of lampenflora (Fabbricatore 2011); their effects are under investigation. No methods to control lampenflora growth were used in the past in the cave (A. Fabbricatore, Director of Grotta Gigante, pers. comm.).

Few published studies are available on the flora and vegetation of the cave. Bussani (1966) reported information on some species of cyanobacteria. Polli and Sguazzin (1998) surveyed the vascular plants and the bryophytes of the entrances and the inner part of Grotta Gigante, providing accurate notes on the distribution of lampenflora throughout the cave; 1 fern and 4 moss species were reported in this work around lamps in the inner part of the cave.

The present paper reports the results of a floristic study of the bryophytes and ferns (land plants) of lampen- 
flora of Grotta Gigante. The main aims of the work are: a) to investigate bryophyte and fern diversity of lampenflora of the cave and compile a species inventory; b) to pro- vide basic knowledge to monitor and control lampenflora growth in Grotta Gigante.

\section{STUDY AREA}

Grotta Gigante is situated in the Trieste Karst, in the municipality of Sgonico (NE Italy). The cave opens into ultrapure Cretaceous limestones at $274 \mathrm{~m}$ a.s.l. It consists of

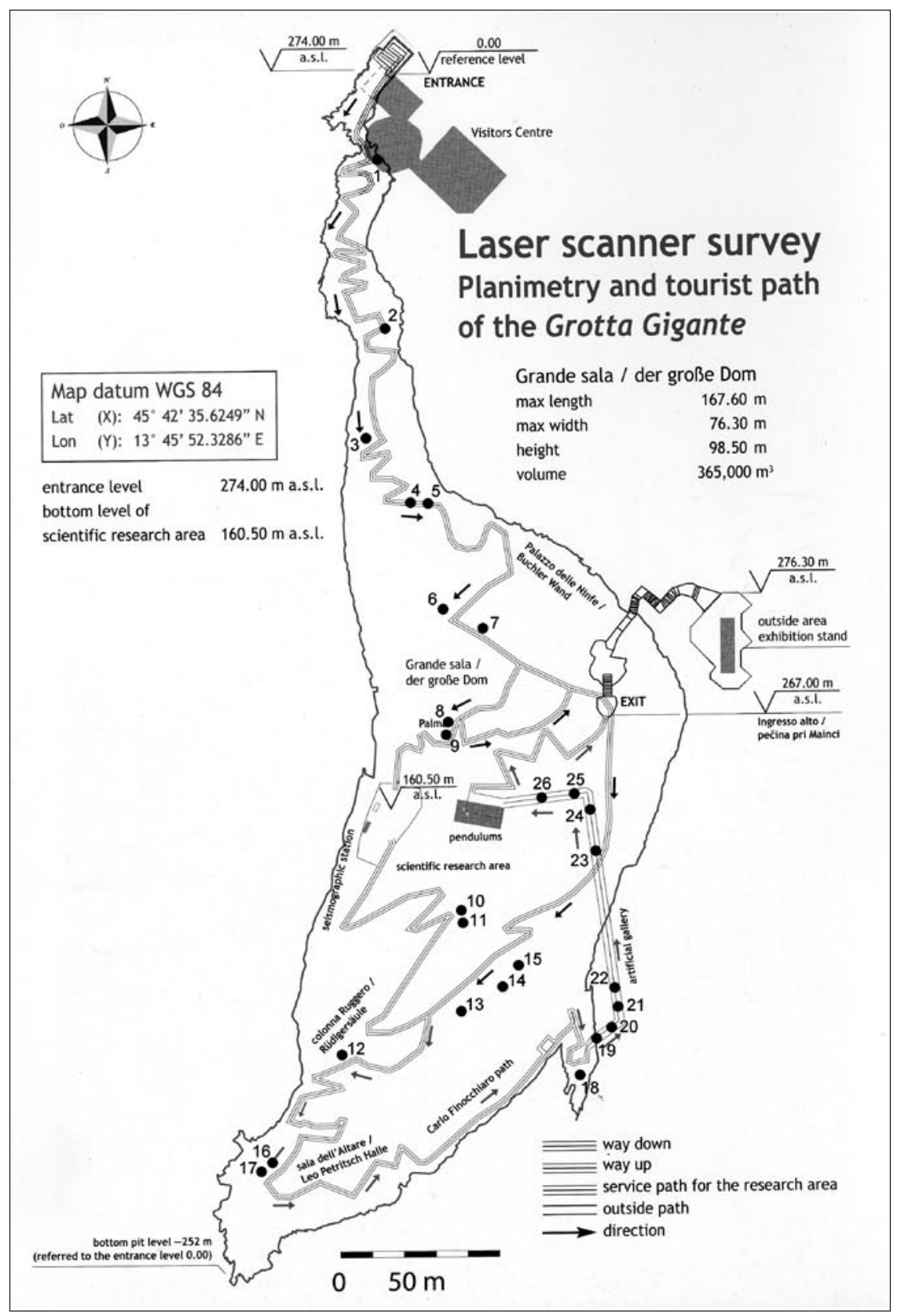

a large chamber ( $167.6 \mathrm{~m}$ long, $98.5 \mathrm{~m}$ high, $76.3 \mathrm{~m}$ wide) which may be accessed through two galleries; it reaches a maximum depth of $252 \mathrm{~m}$ referred to the entrance level

(Fig. 1). Inside the cave, temperature is $11{ }^{\circ} \mathrm{C}$ and relative humidity is $98 \%$.

The lighting system installed in 2009 consists of metal halide and discharge lamp floodlights of different power (from $20 \mathrm{~W}$ to $250 \mathrm{~W})$ and colour temperature $(2,800 \mathrm{~K}$ and $3,000 \mathrm{~K})$ to illuminate the cave interior and formations. The emergency and safety lighting system fitted along cave's pathways consists of $3 \mathrm{~W}$ LED lights and $14 \mathrm{~W}$ warm white fluorescent lamps. A set of UVC germicidal lamps (with 2008 Green certificate) was installed in different parts of the cave to control lampenflora growth; they are switched on every day during closing hours (Fabbricatore 2011).

The cave is open year round, with 7 daily hours of lighting (42 average hours/week) from October to March and 9 daily hours of lighting (57 average hours /week) from April to September. Annual illumination of the show cave is c. 2,580 hours. The average annual number of visitors over the last 30 years is 80,000 , with peaks of 100,000 .

Fig. 1: Map of the study area with location of sampling sites. Map courtesy of Grotta Gigante S.A.G. (Società Alpina delle Giulie); laser scanner survey and graphic processing by O.G.S. (National Institute for Oceanography and Applied Geophysics). 


\section{MATERIALS AND METHODS}

Sampling was carried out in the dark part of the cave from January to July 2012. Bryophytes and ferns were surveyed near lights of different kind (floodlights, LEDs, fluorescent lamps) in microhabitats related to different ecological conditions: type of substrate, inclination, light intensity, water availability (Figs. 2, 3, 4 \& 5). In order to get a comprehensive study of floristic diversity, all safely reachable lit areas with bryophyte and fern cover of spe-

Tab. 1: Number of sampling sites grouped by main type of lights and substrate. Each site corresponds to a lamp, but it may include one or more types of substrate colonized by lampenflora. For light, F: floodlights; FL: fluorescent lamps; LE: LEDs.

\begin{tabular}{lccc}
\hline \multirow{2}{*}{ Substrate } & \multicolumn{3}{c}{ Light } \\
\cline { 2 - 4 } & $F$ & $F L$ & $L E$ \\
\hline Speleothems & 10 & & \\
Main stalagmites & 2 & & \\
Rock walls & 3 & 8 & \\
Clastic sediments, highly degraded rock & 5 & & \\
(debris slopes) & & & \\
Clay (also as thin layer on solid surfaces) & 6 & & \\
Concrete & 1 & & 3 \\
\hline
\end{tabular}

leothems, other cave surfaces and clastic deposits were investigated. As for LEDs and fluorescent lamps along the pathways, all betwen largest vegetated patches found in the different environmental conditions and those spots with species not yet recorded for a particular microhabitat were sampled. Each sampled lamp corresponds to a sampling site, in which one or more relevés were carried out, depending on the variability of ecological conditions occurring at the lamps (e.g. different types or inclination of substrate present at a same lamp, different distance from lamps). 26 sites were sampled in the show cave (Fig. 1, Tab. 1), for a total of 50 relevés of species.

Identification was performed in the field and in the laboratory. For the study of bryophytes, in the laboratory general morphological characters were observed using a stereomicroscope and anatomical characters were studied by light microscopy on hand-cut sections mounted in water. Identification and ecological features of bryophytes were based on Cortini Pedrotti (2001, 2005), Smith (2004) and Atherton et al. (2010). Nomenclature of bryophytes follows Aleffi et al. (2008). Collected specimens are deposited at the University of Trieste Herbarium (TSB).

\section{RESULTS AND DISCUSSION}

A total of 16 moss species ( 9 acrocarps and 7 pleurocarps) and 2 ferns were found around the lamps in the cave; no liverworts were observed (Tab. 2). Seed plants were not noticed inside the cave. The comparison with 8 show caves and 2 mines equipped with electric illumination of the neighbouring Slovenia investigated in recent years by Mulec and Kubešová (2010) shows that, at present, Grotta Gigante hosts the highest number of species (18); in the most species-rich site of Slovenia, Mežica lead and zinc mine, in areas lit 24 hours/day and with an annual illumination of 8,760 hours/sector, 16 taxa were found (Mulec \& Kubešová 2010). The high species diversity of Grotta Gigante may be explained by two main factors: a) high annual illumination hours (c. 2,580), which is a rather high value compared to those of the show caves and mines investigated by Mulec and Kubešová (2010), all below 500 hours/sector with the exception of Mežica lead and zinc mine $(8,760)$ and Postojnska jama $(1,000)$; b) absence of interventions to remove or control lampenflora in the past.

The composition of lampenflora of Grotta Gigante agrees with that found in other Slovenian artificially lit caves and mines investigated starting from the ' 40 (Mulec \& Kubešová 2010). This confirms a substantial homogeneity of lampenflora of caves in the same geographical area.

The most common and widespread mosses found in Grotta Gigante, occurring in more than 50\% of sites, are Eucladium verticillatum, Fissidens bryoides, Oxyrrhynchium schleicheri and Rhynchostegiella tenella; 7 moss species are rare, being found only in 1 to 2 sampling sites (Tab. 2).

Some mosses are known for the flora of wild cave entrances of the Italian Karst (e.g. Polli \& Sguazzin 2002; Sguazzin 2011; Castello \& Strazzaboschi 2013) or favour moist and sheltered places, such as Eucladium verticillatum, Rhynchostegiella tenella, Orthothecium intricatum, Oxyrrhynchium schleicheri. Other mosses are typical of disturbed or open to slightly sheltered habitats, such as Barbula unguiculata, Funaria hygrometrica, Tortula muralis. Almost all mosses are sterile, but $F$. hygrometrica was often found with well-developed sporophytes, and few sporophytes of $R$. tenella were observed at one site. 
Tab. 2: Synthetic table of results of the floristic survey of lampenflora bryophytes and ferns in Grotta Gigante. Species list, number and frequency of occurrence in sites and relevés, main type of lights and substrate. For light, F: floodlights; FL: fluorescent lamps; LE: LEDs. For substrate, S: speleothems; MS: main stalagmites; W: rock walls; CS: clastic sediments and highly degraded rock (landslides); CL: clay (also as thin layer on solid surfaces); CO: concrete along pathways.

\begin{tabular}{|c|c|c|c|c|c|c|c|c|c|c|c|c|c|}
\hline \multirow[t]{3}{*}{ Species } & \multicolumn{4}{|c|}{ Occurrence } & \multicolumn{3}{|c|}{ Light } & \multicolumn{6}{|c|}{ Substrate } \\
\hline & \multicolumn{2}{|c|}{ Sites } & \multicolumn{2}{|c|}{ Relevés } & \multirow[b]{2}{*}{$F$} & \multirow[b]{2}{*}{$F L$} & \multirow[b]{2}{*}{$L E$} & \multirow[b]{2}{*}{$S$} & \multirow[b]{2}{*}{ MS } & \multirow[b]{2}{*}{$w$} & \multirow[b]{2}{*}{ CS } & \multirow[b]{2}{*}{$C L$} & \multirow[b]{2}{*}{$\mathrm{CO}$} \\
\hline & No. & $\%$ & No. & $\%$ & & & & & & & & & \\
\hline \multicolumn{14}{|l|}{ BRYOPHYTES: MOSSES } \\
\hline Amblystegium serpens (Hedw.) Schimp. & 1 & 4 & 2 & 4 & $x$ & & & $x$ & & & & $x$ & \\
\hline Barbula unguiculata Hedw. & 4 & 15 & 4 & 8 & $x$ & & & $x$ & & & $x$ & $x$ & \\
\hline Bryum sp. & 6 & 23 & 8 & 16 & $x$ & $x$ & $x$ & $\mathrm{x}$ & & $\mathrm{x}$ & & $x$ & $x$ \\
\hline Didymodon vinealis (Brid.) R.H. Zander & 3 & 12 & 3 & 6 & $x$ & $x$ & & $x$ & & $x$ & & & $x$ \\
\hline $\begin{array}{l}\text { Eucladium verticillatum (With.) Bruch \& Schimp. var. } \\
\text { verticillatum }\end{array}$ & 23 & 88 & 43 & 86 & $\mathrm{x}$ & $x$ & $\mathrm{x}$ & $x$ & $x$ & $\mathrm{x}$ & $x$ & $\mathrm{x}$ & $x$ \\
\hline Fissidens bryoides Hedw. var. bryoides & 14 & 54 & 24 & 48 & $x$ & $x$ & $x$ & $x$ & & $x$ & $x$ & $x$ & $x$ \\
\hline Funaria hygrometrica Hedw. & 4 & 15 & 6 & 12 & $x$ & & & $x$ & & & $x$ & $x$ & \\
\hline Hygroamblystegium varium (Hedw.) Mönk. & 2 & 8 & 2 & 4 & $x$ & & & $x$ & & & & $x$ & \\
\hline Orthothecium intricatum (Hartm.) Schimp. & 1 & 4 & 1 & 2 & $x$ & & & $x$ & & & & & \\
\hline Oxyrrhynchium pumilum (Wilson) Loeske & 1 & 4 & 1 & 2 & $x$ & & & $x$ & & & & $x$ & \\
\hline Oxyrrhynchium schleicheri (R. Hedw.) Röll. & 14 & 54 & 22 & 44 & $x$ & $\mathrm{x}$ & $x$ & $\mathrm{x}$ & & $x$ & & $x$ & $\mathrm{x}$ \\
\hline Ptychostomum pallens (Sw.) J.R. Spence & 1 & 4 & 1 & 2 & $x$ & & & $x$ & & & & & \\
\hline Rhynchostegiella tenella (Dicks.) Limpr. var. tenella & 15 & 58 & 24 & 48 & $x$ & $x$ & & $\mathrm{x}$ & & $\mathrm{x}$ & $x$ & $x$ & $x$ \\
\hline Rhynchostegium murale (Hedw.) Schimp. & 1 & 4 & 1 & 2 & $x$ & & & $x$ & & & & & \\
\hline Tortula muralis Hedw. & 4 & 15 & 4 & 8 & $x$ & $x$ & & $x$ & & $x$ & & $\mathrm{x}$ & \\
\hline Weissia sp. & 1 & 4 & 1 & 2 & $x$ & & & $\mathrm{x}$ & & & & $x$ & \\
\hline \multicolumn{14}{|l|}{ FERNS } \\
\hline fern prothallus & 6 & 23 & 8 & 16 & $x$ & $x$ & & $x$ & & $x$ & $x$ & $x$ & \\
\hline Asplenium trichomanes $\mathrm{L}$. & 12 & 46 & 19 & 38 & $x$ & $\mathrm{x}$ & $x$ & $x$ & & $x$ & $x$ & $x$ & $x$ \\
\hline Asplenium scolopendrium L. subsp. scolopendrium & 1 & 4 & 1 & 2 & $x$ & & & $\mathrm{x}$ & & & & & \\
\hline
\end{tabular}

As for ferns, Asplenium trichomanes is common throughout the cave; small plants are usually found around lamps, but well-developed individuals occur in highly lit sites wet by continuous dripping water. Asplenium scolopendrium in development in one site is a new record for the inner part of the cave. According to Polli and Sguazzin (1998), the species, which has been de-

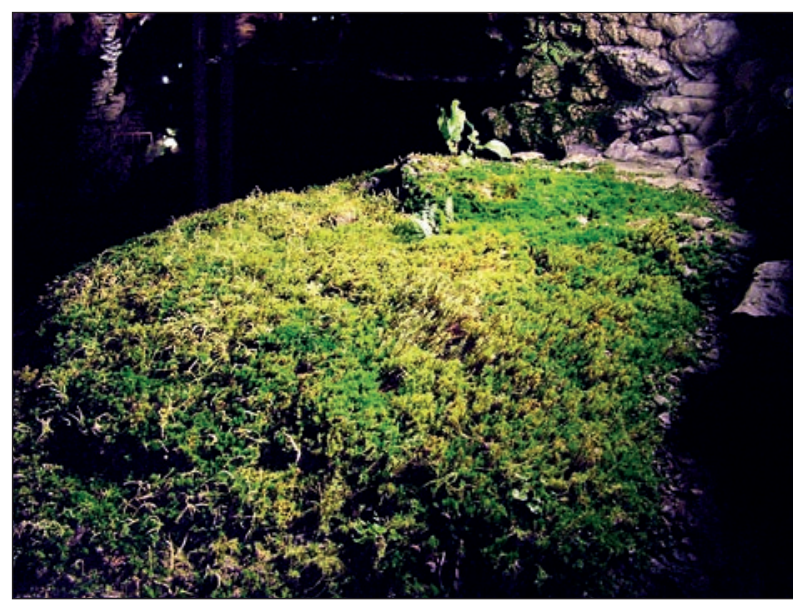

Fig. 2: A well developed lampenflora community dominated by mosses in Grotta Gigante. creasing and disappearing from many Karst caves in the past decades probably due to climatic changes, grew in the past at the cave's entrance but it went extinct some decades ago. These authors did not observe the species inside the cave. A few plants were later re-introduced in the outer part of the cave near the exit (archive of Grotta Gigante), where they are still present.

The most common species inside the cave is the moss Eucladium verticillatum, which occurs in $88 \%$ of sites and $86 \%$ of relevés (Tab. 2). This is one of the most important tufa-forming mosses; it promotes calcium carbonate deposition and lower parts of stems are often encrusted with calcium carbonate (Glime 2007; Atherton et al. 2010). In Grotta Gigante this moss favours moist surfaces of different kind; it was collected over a wide range of substrates and light intensities, from very well lit to deep shaded areas around the lamps, as found by Mulec and Kubešová (2010) in show caves of Slovenia.

All moss and fern species reported in the previous study of lampenflora by Polli and Sguazzin (1998) (Amblystegium serpens, Bryum sp., Eucladium verticillatum, Fissidens bryoides and the fern Asplenium trichomanes) were found in this survey. 
As for main ecological factors influencing lampenflora in the cave, no particular zonation of bryophyte and fern vegetation was observed along decreasing light gradient around lights, as found by Mulec et al. (2008) for aerophytic algal communities in Slovenian caves. Various mosses and Asplenium trichomanes were observed growing over a relatively wide range of light intensity, in accordance with the findings by Mulec and Kubešová (2010). The poorly lit, most distant areas from lamps are characterized by the constant occurrence of Eucladium verticillatum; sometimes some reduced plants of $A$. trichomanes are present there as well.

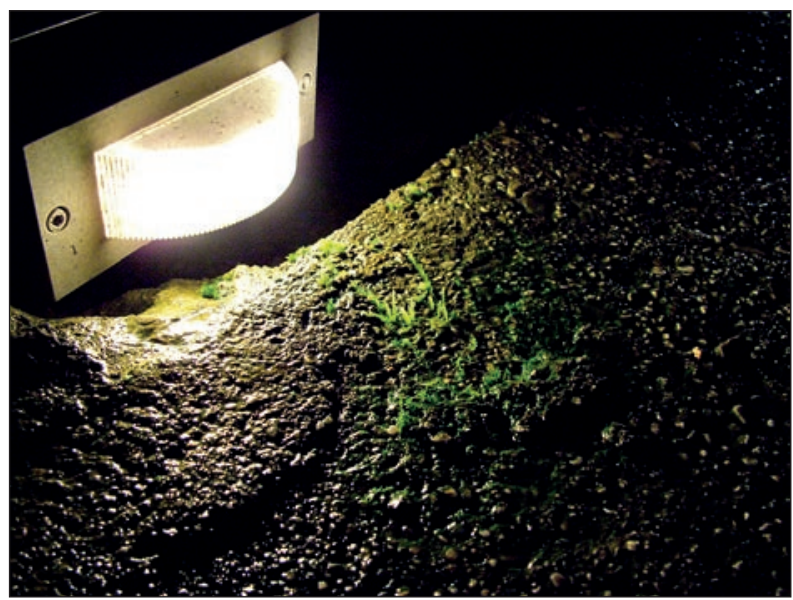

Fig. 3: Small mosses around LED lamps installed along the pathways in 2009.

The influence of the main types of lights (floodlights, LEDs and fluorescent lamps) on species occurrence could not be fully assessed, as lamps of different type are positioned in different ecological conditions. LEDs were installed in 2009 as step lights for pathways and stairs and they lit mainly concrete areas (Fig. 3); fluorescent lamps were fitted in 2009 at the base of the rock walls of an artificial gallery (Fig. 4); floodlights are positioned on various cave formations and substrata in areas illuminated at different starting times. LEDs and fluorescent lamps were all installed in 2009 in new positions, therefore investigated sites around them correspond to the first stages of ecological succession. All species observed around LEDs and fluorescent lamps were found near the other lights (Tab. 2); this shows that in Grotta Gigante at least a set of species are not affected by types of lights. The reduced number of species found near LEDs and fluorescent lamps compared to floodlights could be influenced by different light features, but also simply by the shorter time available for community development. However, it is evident that in areas lit by LEDs lampenflora growth is limited both in number of species and biomass in comparison to fluorescent lamps.

Substrate type seems to play a minor ecological role for some species, such as Eucladium verticillatum and Asplenium trichomanes, but it influences the occurrence of others. Tortula muralis, for instance, was mainly found on the rock walls of the artificial gallery. The permanently wet, lit surfaces of cave speleothems are dominated by E. verticillatum and avoided by other mosses: lit parts of the main stalagmites of the show cave, the "Palma" and the "Colonna Ruggero", are colonized by patches of this species. Fissidens bryoides thrives on clay, even if present as a thin layer on rocks and formations. Clay influences both moisture and mineral nutrient content of the substrate, promoting plant growth: in Grotta Gigante surfaces with clay support the growth of extensive patches of mosses, up to c. $4 \mathrm{~m}^{2}$ wide (Fig. 5), as reported in the literature (e.g. Johnson 1980).

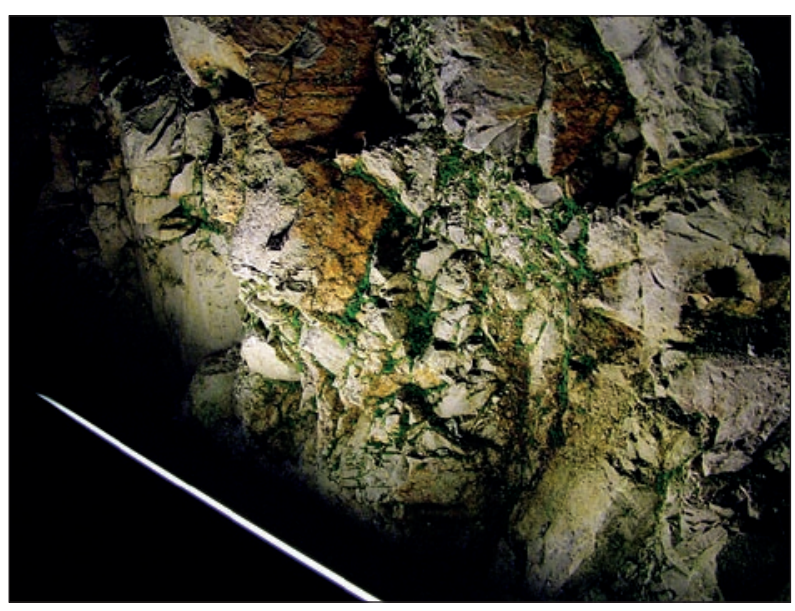

Fig. 4: Lampenflora colonizing the wet walls of an artificial tunnel around fluorescent lamps fitted in 2009.

Surface morphology is a relevant ecological factor for species growth. Surface topography and roughness, and porosity of the substrate strongly influence bioreceptivity of materials. They influence water and nutrients availability for organisms; furthermore, they affect the settlement of spores, cells and vegetative propagules and the attachment of the plants (e.g. Warscheid \& Braams 2000; Mulec 2012). This was also observed for substrata of Grotta Gigante: surface irregularities, rough or porous materials promote the colonization by organisms and the proliferation of dense patches of lampenflora, and affect its distribution near the lamps.

The survey of safety lights installed along the pathways in 2009 shows that a colonizing process is in act, involving microalgae, which are typical pioneer species in lampenflora ecological succession, but also mosses 
and ferns, which usually appear in later stages (Mulec \& Kubešová 2010). Near various LED lamps installed along the steps of the downwards pathway, green patches of microalgae were found, but near some LEDs small, very scattered individuals of Bryum sp., Eucladium verticillatum, Fissidens bryoides, Oxyrrhynchium schleicheri, sometimes accompanied by single small shoots of Asplenium trichomanes were observed, extending up to a distance of $15 \mathrm{~cm}$ from the lights (Tab. 2, Fig. 3). In the artificial tunnel along the Carlo Finocchiaro path, opened to the public in 1996, lampenflora is colonizing the moist calcareous walls around almost all the fluorescent lamps, with Bryum sp., Didymodon vinealis, Eucladium verticillatum, Fissidens bryoides, Oxyrrhynchium schleicheri,

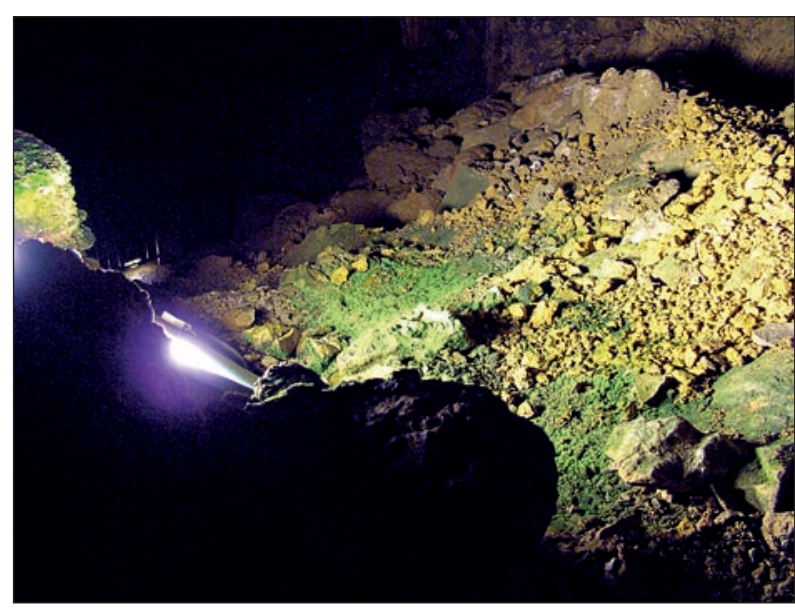

Fig. 5: Clastic deposits and clay promote the growth of large patches of mosses.
Rhynchostegiella tenella, Tortula muralis and small plants of A. trichomanes, forming large patches extended up to c. $60 \mathrm{~cm}$ from the lights (Tab. 2, Fig. 4). Previous work by Polli and Sguazzin (1998) confirms the ongoing colonizing process: along the steps of the downwards staircase mosses or ferns were not observed by these authors, while in the artificial gallery a reduced zone with mosses was noticed around just one single lamp.

The present study provides further evidence that established lampenflora is able to survive for long periods of darkness, as reported in the literature (e.g. Johnston 1980; Eliot 2006; Mulec \& Kosi 2009; Mulec 2011; Cigna 2011). Shortly before the survey, a lamp failed leaving the surrounding area completely dark and it was replaced after c. 7 months; the site was investigated two months later. Mosses did not show particular damages; many patches of calcified filamentous cyanobacteria, several prothalli and small shoots of Asplenium trichomanes were observed. The ability to withstand long periods of darkness may be linked to particular physiological features of plants of lampenflora, which are mainly shade-adapted, stress-tolerant organisms, able to survive under adverse environmental conditions even over long periods. Control of lampenflora growth based on periodical closing of show caves lasting some weeks or months to reduce lighting time is likely to have no particular advantage, as prolonged periods without illumination do not seem to reduce established lampenflora, may favour the development of some organisms as cyanobacteria, and may be very problematic for the economic management of show caves (see also Mulec \& Kosi 2009; Cigna 2011).

\section{CONCLUSIONS}

In the inner part of Grotta Gigante 16 mosses and 2 ferns were found around the artificial lights, for a total of 18 land plants. Species richness of the cave is the highest compared to other recently investigated show caves and mines of the neighbouring Slovenia (Mulec \& Kubešová 2010). Only some species are common throughout the cave, while many other occur in one or few sites. The high number of species found in the cave may be mainly explained by the light regime, with a rather high number of annual lighting hours (c. 2,500 hours/year) and by the absence of interventions to remove lampenflora in the past. The moss Eucladium verticillatum is the most common and abundant species in the cave; it favours wet rock surfaces and it shows a remarkable ecological plasticity, being able to grow over a wide range of substrates and light intensities.
The main ecological factors affecting lampenflora in Grotta Gigante identified in this work, and corresponding to the results of studies from other caves, are: light intensity, water availability, type of substrate, morphological features of surfaces, presence of clay.

Observations on the distribution of bryophytes and ferns in Grotta Gigante support many guidelines recommended in the literature to control lampenflora growth. In particular, light installation should be avoided or limited on damp and moist surfaces, as simultaneous availability of water and light greatly promotes lampenflora growth. Similarly, areas with mud or clay should not be directly lit.

An environmentally sustainable strategy to control lampenflora growth should mainly rely on an ecological approach based on minimizing the energy input of arti- 
ficial lighting in the underground ecosystems. Cleaning methods are able to control lampenflora only for short periods and may have negative effects on other cave organisms, speleothems and on the staff and visitors as well: if artificial lighting is kept, lampenflora will reappear, as propagules are constantly present inside a cave (Mulec 2012). Lampenflora can be ecologically controlled in the long term by limiting light eutrophication of caves, which promotes the growth of phototrophs. This may be achieved by an adeguate cave lighting design and regime, thoughtfully planned to reduce intensity and duration of illumination and with particular attention to type, power and installation sites of lights (e.g. Olson 2006; Mulec \& Kosi 2009; Cigna 2012; Mulec 2011, 2012). The development of microalgae, mosses and small ferns around
LEDs in a few years time observed in Grotta Gigante highlights that LED lighting is not sufficient by itself to prevent lampenflora growth: in any case, great attention must be paid to intensity and emission spectrum of LED lights. This ecologically-based approach to control lampenflora could reduce the frequency and the costs of cleaning interventions, resulting advantageous for both the environment and the economic management of a show cave.

Thanks to the long history as a show cave, the absence of interventions to control lampenflora in the past and the possibility to date new installation of several lamps, Grotta Gigante represents an interesting case study for research on lampenflora.

\section{ACKNOWLEDGEMENTS}

The author would like to thank Michele Codogno and Andrea Nardini (University of Trieste) for valuable discussions and suggestions, Salvatore Branca and Luca Strazzaboschi for their help in field work. Special thanks go to the director of Grotta Gigante, Alessio Fabbrica- tore, and to the staff of the cave for their kind support and collaboration. The research was carried out within a collaboration framework between Grotta Gigante S.A.G. and the University of Trieste.

\section{REFERENCES}

Aleffi, M., Tacchi, R. \& C. Cortini Pedrotti, 2008: Checklist of the Hornworts, Liverworts and Mosses of Italy.- Bocconea, 22, 1-256.

Atherton, I., Bosanquet, S. \& M. Lawley (eds.), 2010: Mosses and Liverworts of Britain and Ireland. A field guide.- British Bryological Society, Latimer Trend \& Co., pp. 848, Plymouth.

Bussani, M., 1966: Le Cianoficee nelle cavità carsiche.Atti e Memorie Commissione Grotte "E. Boegan", 5 (1965), 107-109.

Castello, M. \& L. Strazzaboschi, 2013: Le briofite della Grotta dell'Orso (33-7VG, Carso Triestino, NE Italia).- Atti e Memorie Commissione Grotte "E. Boegan", 44, 55-71.

Cigna, A.A., 2011: The problem of lampenflora in show caves.- In: Bella, P. \& P. Gažík (eds.) ISCA 6th Congress Proceedings, $18^{\text {th }}-23^{\text {rd }}$ October 2010, Demänovská Dolina, Liptovský Mikuláš, Slovakia. State Nature Conservancy of the Slovak Republic, Slovak Caves Administration, 201-205, Slovakia.
Cigna A.A., 2012: Show caves. In: White, W.B. \& D.C. Culver (eds.) Encyclopedia of Caves, Second Edition. Academic Press, pp. 690-697, Chennai.

Cortini Pedrotti, C., 2001: Flora dei muschi d'Italia. Sphagnopsida, Andreaeopsida, Bryopsida (I parte).Antonio Delfino Editore, pp. 832, Roma.

Cortini Pedrotti, C., 2005: Flora dei muschi d'Italia. Bryopsida (II parte).- Antonio Delfino Editore, pp. 432, Roma.

Dobàt, K., 1963: "Höhlenalgen" bedrohen die Eiszeitmalereien von Lascaux.- Die Höhle, Wien, 14, 2, 41-45.

Dobàt, K., 1998: Flore de la lumiére artificiélle (lampenflora-maladie verte).- In: Juberthie, C. \& V. Decu (eds.) Encyclopaedia biospeleologica, Tome 2, Société de Biospéologie, 1325-1335, Moulis-Bucarest.

Elliott, W. R., 2006: Biological Dos and Don'ts of Cave Restoration and Conservation.- In: Hildreth-Werker, V. \& J.C. Werker (eds.) Cave Conservation and Restoration. National Speleological Society, pp. 3346, Huntsville, Alabama U.S.A. 
Fabbricatore, A., 2011: The new electrical system of the Grotta Gigante: compliance with the laws in force and lighting study - The Grotta Gigante as a tourist and scientific centre.- In: Bella, P. \& P. Gažík (eds.) ISCA $6^{\text {th }}$ Congress Proceedings, $18^{\text {th }}-23^{\text {rd }}$ October 2010, Demänovská Dolina, Liptovský Mikuláš, Slovakia. State Nature Conservancy of the Slovak Republic, Slovak Caves Administration, 62-70, Slovakia.

Glime, J.M., 2007: Light: cave mosses.- In: Bryophyte ecology, Volume 1, Physiological ecology. Ebook sponsored by Michigan Technological University and the International Association of Bryologist.[Online] Available from: http://www.bryoecol.mtu. edu/ [Accessed 10 $0^{\text {th }}$ September 2012].

Johnson, K., 1980: Control of lampenflora at Waitomo Caves, New Zealand.- In: Robinson A. C. (ed.) Cave Management in Australia III: Proceedings of the third Australian Conference on cave tourism and management, $30^{\text {th }}$ April-4 ${ }^{\text {th }}$ May 1979, Mount Gambier, South Australia. National Parks and Wildlife Service, Adelaide and Australian Speleological Federation, 105-122, Adelaide.

Mulec, J., 2011: Lampenflora in show caves in Slovenia. In: Prelovšek, M. \& N. Zupan Hajna (eds.) Pressures and Protection of the Underground Karst - Cases from Slovenia and Croatia. Karst Research Institute ZRC SAZU, 64-73, Postojna.

Mulec, J., 2012: Lampenflora. In: White, W.B. \& D.C. Culver (eds.) Encyclopedia of Caves, Second Edition. Academic Press, pp. 451-456, Chennai.

Mulec, J. \& G. Kosi, 2009: Lampenflora algae and methods of growth control.- Journal of Cave and Karst Studies, 71, 2, 109-115.
Mulec, J. \& S. Kubešová, 2010: Diversity of bryophytes in show caves in Slovenia and relation to light intensities.- Acta Carsologica, 39, 3, 587-596.

Mulec, J., Kosi, G. \& D. Vrhovšek, 2008: Characterization of cave aerophytic algal communities and effects of irradiance levels on production of pigments.- Journal of Cave and Karst Studies, 70, 1, 3-12.

Olson, R., 2006: Control of lamp flora in developed caves.- In: Hildreth-Werker, V. \& J.C. Werker (eds.) Cave Conservation and Restoration. National Speleological Society, pp. 343-348, Huntsville, Alabama U.S.A.

Polli, E. \& F. Sguazzin, 1998: Aspetti vegetazionali della Grotta Gigante (2 VG): le piante vascolari ed il componente briologico. Atti e Memorie Commissione Grotte "E. Boegan", 35 (1997), 63-80.

Polli, E. \& F. Sguazzin, 2002: Felci e briofite rinvenute in recenti esplorazioni speleobotaniche sul Carso triestino.- Pagine Botaniche, 27, 3-20.

Sguazzin, F., 2011: Check-list delle Briofite del Friuli Venezia Giulia (NE Italia).- Gortania, 32 (2010): 17-114.

Simon, K.S., Pipan, T. \& D.C. Culver, 2007: A conceptual model of the flow and distribution of organic carbon in caves.- Journal of Cave and Karst Studies, 69, 2, 279-284.

Smith, A.J.E., 2004: The Moss flora of Britain and Ireland.Cambridge University Press, pp. 1026, Cambridge.

Warscheid, Th. \& J. Braams, 2000: Biodeterioration of stone: a review.- International Biodeterioration \& Biodegradation, 46, 343-368. 